\title{
THE CENTENNIAL OF IOWA TERRITORY
}

On the twelfth day of June, 1838, President Martin Van Buren signed a congressional act providing for the establishment of the Territory of Iowa and the civil government therein "from and after July 3, 1838". This act, which set Iowa upon the highroad that led to statehood and admission into the Union eight and a half years later, will be observed throughout Iowa in the coming year by local and state organizations everywhere. In order that the significance of our territorial period may be the better recognized, and its observance be as wide spread as possible, we are reprinting in this issue the congression act signed by President Van Buren. At this time it seems equally fitting that we should recall other well known facts concerning Iowa's development from raw uncharted prairies, its rise from military rule and Indian occupation to white settlement and civil rule, to territorial status, and the achievement of the crown of statehood.

A brief review of this chain of events will best be seen in the chronology of the steps through which the sovereignty over the Iowa country passed from several foreign powers to the United States, of the steps necessary before eivil government was locally obtained, and of the steps taken before the present state boundaries were acquired. Such a review should suggest that although possessing sovereignty, questions of Indian title and white settlement remained to perplex and harass the government, that federal jurisdiction and was not always synonymous with white settlement, and that organized civil government did not always go hand in hand with white settlement.

The dates given below are those furnished by Mr. C. C. Stiles, superintendent of the Public Archives Division of the Historical, Memorial and Art Department from his long familiarity with Iowa records and Iowa authorities.

1682-Cavalier Robert de La Salle took possession of the entire Mississippi Valley for France, and named it Louisiana.

1762-France ceded the Louisiana territory to Spain by the secret treaty of November 3, 1762. 
1800 - Spain receded Louisiana to France by the secret treaty of Sans Tldefonso, Octnber 1, 1800.

1803-United States purchased Louisiana from France. Treaty signed April 30, 1803, ratified October 19, 1803.

Louisiana Purchase governed by presidential deeree. October 31, 1803.

1804 -District of Louisiana established and placed under the jurisdietion of the governor and judges of Indiana Territory, March 26, 1804.

Sauk and Fox Indians cede land in Missouri, Wiseonsin, and Illinois to the United States, in return receive sole right of oceupation. November $3,1804$.

1805-Territory of Louisiana established, included Iowa country. July 4, 1805 .

1812-Territory of Missouri established, December 7, 1812. Included Iowa country.

1821-1834-Missouri admitted into the Union, August 10, 1821. Iowa without the jurisdiction of eivil laws from August 10, 1821 until June 28, 1834.

1833- Sauk and Fox Indians cede title and right of white settlement in area west of the Mississippi known as the "Black Hawk Purchase." Open to settlement June 1, 1833. 400 square miles reserved on the lower banks of the Iowa river for Keokuk's reservation. Treaty of September 21, 1832, closing the Black Hawk War, ratified February 13, 1833.

1834-Iowa country made a part of Michigan Territory giving it the protection of the civil law eourts. June 28, 1834 .

Half-breed tract opened to white settlement by the act of Congress granting half-breeds title in fee simple. June 30, 1834.

First local eivil government organized by the ereation of Des moines and Dubuque counties, September 6, 1834.

1836-Iowa country made a part of Wisconsin Territory on its establishment on July $3,1836$.

1837-Keokuk's reservation ceded to the United States with right of white settlement. Treaty of September 28, 1836, ratified February 27, 1837. Amended treaty ratified December 13, 1837.

1838-Sauk and Fox Indians cede 1,250,000 acres adjoining the original purchase (treaty of 1832), to the United States for white settlement. Treaty of Oetober 21, 1837, ratified February 21, 1838. Sauk and Fox of the Missouri cede to the United States all right and title to land between the Missouri and Mississippi rivers, held by right of six different treaties. Treaty of October 21, 1837, ratified February 21, 1838.

Winnebagos cede all right to occupy the Neutral Ground (treaty of September 15, 1832) for twenty miles from the Mississippi boundaries, agree to but a temporary oceupation of the western 


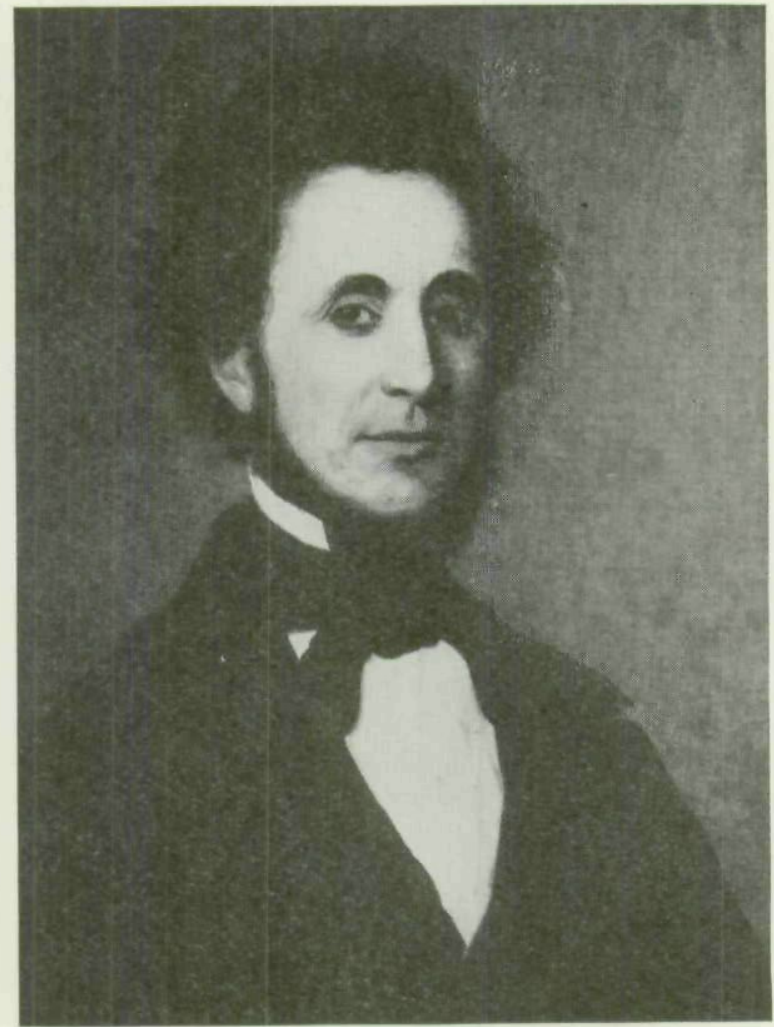

An Early Portrait of GEORGE WALLACE JONES

April 12, 1804 -July 22, 1896

Territorial Delegate from Michigan 1835-1836

Territorial Delegate from Wisconsin 1836-1838

U. S. Senator from Iowa 1848-1859

Minister to Bogota (Columbia) 1859.1861

portion. Treaty of November 1, 1837, ratified June 15, 1838. Ioway Indians eede all rights to territory claimed in treaty of July 15, 1830. Treaty of November 23, 1837, ratified February 21, 1838 .

Sioux (Yancton band), eede all rights to land held by treaty of July 15, 1830. Treaty of Oetober 21, 1831, ratified February 21, 1838.

Iowa-Missouri boundary line enters a long history of official dispute, settled only on January 3, 1838. 
1839-Ioway Indians cede all right and title to land between the Mis souri and Mississippi rivers. Treaty of Oetober 19, 1838, ratified March 2, 1839.

Eastern boundary, Mississippi river channels, set by Congress, Mareh 3, 1839.

1843-Sauk and Fox cede all rights and title to land between the Missouri and Mississippi rivers, retaining the right to occupy the western portion for three years. Treaty of October 11, 1842, ratified Mareh 23, 1843.

1845-Admission of Iowa into the Union provided for, with area but half of that of the present state. March 3, 1845.

1846-The Pottawatomie Nation (Chippewas, Ottowas, and three bands of Pottawatomies) cede all rights to land between the Missouri and Mississippi rivers. Treaty of June 5 and 17, 1846, ratified July 23, 1846.

Present boundaries of Iowa agreed to by Congress, August 4, 1846. Iowa admitted into the Union, December 28, 1846.

1847-Winnebagos cede all rights to any land of the United States claimed by them, especially ceding all claim to the Neutral Ground. Treaty of Oetober 21, 1846, ratified February 4, 1847.

1851-By decree of the United States Supreme Court the Iowa-Missouri boundary line dispute settled by acceptance of the General Land Office survey of the 1816 Sullivan line. January 3, 1851.

1853-Sioux Indians cede all rights to land in the State of Iowa. Treaty of July 23, 1851, ratified February 24, 1853.

Sioux (other bands), cede all rights to lands elaimed in the State of Iowa. Treaty of Aug. 5, 1851, ratified Feb. 24, 1853.

AN ACT to divide the Territory of Wisconsin, and to establish the Territorial Government of Iowa.

Be it enacted by the Senate and House of Representatives of the United States of America, in Congress assembled, That, from and after the third day of July next, all that part of the present Territory of Wisconsin which lies west of the Mississippi river, and west of a line drawn due north from the head waters or sources of the Mississippi to the territorial line, shall, for the purposes of temporary government, be and constitute a separate territorial government, by the name of Iowa; and that, from and after the said third day of July next, the present territorial government of Wisconsin shall extend only to that part of the present Territory of Wisconsin which lies east of the Mississippi river. And after the said third day of July next, all power and authority of the government of Wisconsin, in and over the territory hereby con- 
stituted, shall cease: Provided, That nothing in this act contained, shall be construed to impair the rights of person or property now appertaining to any Indians within the said Territory, so long as such rights shall remain unextinguished by treaty between the United States and such Indians, or to impair the obligations of any treaty now existing between the United States and such Indians, or to impair or anywise to affect the authority of the government of the United States to make any regulations respecting such Indians, their lands, property, or other rights, by treaty, or law, or otherwise, which it would have been competent to the government to make if this act had never been passed: Provided, That nothing in this act contained shall be construed to inhibit the government of the United States from dividing the territory hereby established into one or more other territories, in such manner, and at such times, as Congress shall, in its diseretion, deem convenient and proper, or from attaching any portion of said Territory to any other State or Territory of the United States.

Sec. 2. And be it further enacted, That the Executive power and authority in and over the said Territory of Iowa, shall be vested in a Governor, who shall hold his office for three years, unless sooner removed by the President of the United States. The governor shall reside within the said Territory, shall be commander-in-chief of the militia thereof, shall perform the duties and receive the emoluments of superintendent of Indian affairs, and shall approve of all laws passed by the Legislative Assembly, before they shall take effect; he may grant pardons for offenses against the laws of the said Territory, and reprieves for offences against the law of the United States, until the decision of the President ean be made known thereon; he shall commission all officers who shall be appointed to office under the laws of the said Territory, and shall take care that the laws be faithfully executed.

Sec. 3. And be it further enacted, That there shall be a secretary of the said Territory, who shall reside therein, and hold his office for four years, unless sooner removed by the President of the United States; he shall record and preserve 
all the laws and proceedings of the Legislative Assembly hereinafter constituted, and all the acts and proceedings of the governor in his executive department; he shall transmit one copy of the laws and one copy of the executive proceedings, on or before the first Monday in December in each year, to the President of the United States; and, at the same time, two copies of the laws to the Speaker of the House of Representatives, for the use of Congress. And in case of the death, removal, resignation, or necessary absence of the governor from the Territory, the secretary shall have, and he is hereby authorized and required to execute and perform all the powers and duties of the governor during such vacancy or necessary absence, or until another governor shall be duly appointed to fill such vacancy.

Sec. 4. And be it further enacted, That the legislative power shall be vested in the governor and a legislative assembly. The legislative assembly shall eonsist of a Council and House of Representatives. The Council shall consist of thirteen members, having the qualifications of voters as hereinafter prescribed, whose term of service shall continue two years. The House of Representatives shall eonsist of twentysix members possessing the same qualifications as prescribed for the members of the Couneil, and whose term of service shall continue one year. An apportionment shall be made, as nearly equal as practicable, among the several counties, for the election of the Council and Representatives, giving to each section of the Territory representation in the ratio of its population, Indians excepted, as nearly as may be. And the said members of the Council and House of Representatives shall reside in, and be inhabitants of the district for which they may be elected. Previous to the first election, the governor of the Territory shall cause the census or enumeration of the inhabitants of the several counties in the Territory, to be taken and made by the sheriffs of the said counties respectively, unless the same shall have been taken within three months previous to the third day of July next, and returns thereof made by said sheriffs to the governor. The first election shall be held at such time and place, and be conducted 
in such manner as the governor shall appoint and direct; and he shall, at the same time, declare the number of members of the Council and House of Representatives to which each of the counties or districts are entitled under this act. The number of persons authorized to be elected having the greatest number of votes in each of the said counties or districts for the Council, shall be declared by the said governor to be duly elected to the said Council; and the person or persons having the greatest number of votes for the House of Representatives, equal to the number to which each county may be entitled, shall also be declared by the governor to be duly elected: Provided, the governor shall order a new election when there is a tie between two or more persons voted for, to supply the vacancy made by such tie. And the persons thus elected to the legislative assembly shall meet at such place and on such day as he shall appoint; but thereafter, the time, place and manner of holding and conducting all elections by the people, and apportioning the representation in the several counties to the Council and House of Representatives, according to population, shall be preseribed by law, as well as the day of the annual commencement of the session of the said legislative assembly; but no session, in any year, shall exceed the term of seventy-five days.

Sec. 5. And be it further enacted, That every free white male citizen of the United States, above the age of twenty-one years, who shall have been an inhabitant of said Territory at the time of its organization, shall be entitled to vote at the first election and shall be eligible to any office within the said Territory; but the qualifications, of voters, at all subsequent elections, shall be such as shall be determined by the legislative assembly; Provided, that the right of suffrage shall be exereised only by citizens of the United States.

Sec. 6. And be it further enacted, That the legislative power of the Territory shall extend to all rightful subjects of legislation; but no law shall be passed interfering with the primary disposal of the soil; no tax shall be imposed upon the property of the United States; nor shall the land or other property of non-residents be taxed higher than the lands or other property of residents. All the laws of the governor and legislative assembly shall be submitted to, and if disapproved 
by the Congress of the United States, the same shall be null and of no effect.

Sec. 7. And be it further enacted, That all township officers, and all county officers, except judicial officers, justices of the peace, sheriffs, and clerks of courts, shall be elceted by the people, in such manner as is now preseribed by the laws of the Territory of Wisconsin, or as may, after the first election, be provided by the governor and legislative assembly of Iowa Territory. The governor shall nominate, and, by and with the advice and consent of the legislative council, shall appoint all judicial officers, justices of the peace, sheriffs, and all militia officers, except those of the staff, and all civil officers not herein provided for. Vacancies oceurring in the recess of the Council, shall be filled by appointments from the governor, which shall expire at the end of the next session of the legislative assembly; but the said governor may appoint, in the first instance, the aforesaid officers, who shall hold their offices until the end of the next session of the said legislative assembly.

Sec. 8. And be it further enacted, That no member of the legislative assembly shall hold, or be appointed to, any office created, or the salary or emoluments of which shall have been increased whilst he was a member, during the term for which he shall have been elected, and for one year after the expiration of such term, and no person holding a commission or appointment under the United States, or any of its officers, except as a militia officer, shall be a member of the said Council or House of Representatives, or shall hold any office under the government of the said Territory.

Sec. 9. And be it further enacted, That the judicial power of the said Territory shall be vested in a supreme court, district courts, probate courts, and in justices of the peace. The supreme court shall consist of a chief justice and two associate judges, any two of whom shall be a quorum, and who shall hold a term at the seat of government of the said Territory annually; and they shall hold their offices during the term of four years. The said Territory shall be divided into three judicial districts; and a district court or courts shall be held in each of the three districts, by one of the 
judges of the supreme court, at such times and places as may be prescribed by law; and the said judges shall, after their appointment, respectively, reside in the district which shall be assigned to them. The jurisdiction of the several courts herein provided for, both appellate and original, and that of the probate courts, and of the justices of the peace, shall be as limited by law: Provided, however, that justices of the peace shall not have jurisdiction of any matter of controversy, when the title or boundaries of land may be in dispute, or where the debt or sum elaimed exceeds fifty dollars. And the said supreme and district courts, respectively, shall possess a chancery as well as a common law jurisdiction.-Each district court shall appoint its clerk, who shall keep his office at the place where the court may be held, and the said clerks shall also be the registers in chancery; and any vacancy in said office of clerk, happening in the vacation of said court, may be filled by the judge of said district, which appointment shall continue until the next term of said court. And writs of error, bills of exception, and appeals in chancery causes, shall be allowed in all cases, from the final decisions of the said district courts to the supreme court, under such regulations as may be prescribed by law; but in no case, removed to the supreme court, shall trial by jury be allowed in said court. The supreme court may appoint its own clerk, and every clerk shall hold his office at the pleasure of the court by which he shall have been appointed. And writs of error and appeals from the final decision of the said supreme court shall be allowed and taken to the supreme court of the United States, in the same manner and under the same regulations as from the circuit courts of the United States, where the value of the property, or the amount in controversy, to be ascertained by the oath or affirmation of either party, shall exceed one thousand dollars. And each of the said district courts shall have and exercise the same jurisdiction in all eases arising under the constitution and laws of the United States, as is vested in the circuit and district courts of the United States.-And the first six days of every term of the said courts, or so much thereof as shall be necessary, shall be appropriated to the trial of causes arising under the said constitution and 
laws. And writs of error and appeals from the final decisions of the said courts, in all such cases, shall be made to the supreme court of the Territory, in the same manner as in other cases. The said elerks shall receive, in all such eases, the same fees which the clerk of the district courts of Wisconsin Territory now receives for similar services.

Sec. 10. And be it further enacted, That there shall be an attorney for the said Territory appointed, who shall continue in office four years, unless sooner removed by the president, and who shall receive the same fees and salary as the attorney of the United States for the present Territory of Wisconsin. There shall also be a marshal for the Territory appointed, who shall hold his office for four years, unless sooner removed by the president, who shall execute all process issuing from the said courts when exereising their jurisdiction as eireuit and district courts of the United States. He shall perform the same duties, be subject to the same regulations and penalties, and be entitled to the same fees as the marshal of the district court of the United States for the present Territory of Wisconsin; and shall, in addition, be paid the sum of two hundred dollars annually as a compensation for extra services.

Sec. 11. And be it further enacted, That the governor, secretary, chief justice and associate judges, attorney, and marshal, shall be nominated, and by and with the advice and consent of the Senate, appointed by the president of the United States. The governor and secretary, to be appointed as aforesaid, shall, before they act as such, respectively take an oath or affirmation, before some judge or justice of the peace in the existing Territory of Wisconsin, duly commissioned and qualified to administer an oath or affirmation, or before the chief justice or some associate justice of the supreme court of the United States, to support the constitution of the United States, and for the faithful discharge of the duties of their respective offices; which said oaths, when so taken, shall be certified by the person before whom the same shall have been taken, and such certificate shall be received and recorded by the said secretary among the executive proceedings. And, afterwards, the chief justice and associate judges, and all other civil officers in said Territory, before they act 
as such, shall take a like oath, or affirmation, before said governor, or secretary, or some judge or justice of the territory, who may be duly commissioned and qualified, which said oath or affirmation shall be certified and transmitted, by the person taking the same, to the secretary, to be by him recorded as aforesaid; and, afterwards, the like oath or affirmation shall be taken, certified, and recorded in such manner and form as may be preseribed by law. The governor shall receive an annual salary of fifteen hundred dollars as governor, and one thousand dollars as superintendent of Indian affairs. The said chief judge and associate justices shall each receive an annual salary of fifteen hundred dollars. The secretary shall receive an annual salary of twelve hundred dollars. The said salaries shall be paid quarter yearly, at the treasury of the United States. The members of the legislative assembly shall be entitled to receive three dollars each per day, during their attendance at the session thereof; and three dollars each for every twenty miles travel in going to, and returning from the said sessions, estimated according to the nearest usually travelled route. There shall be appropriated, annually, the sum of three hundred and fifty dollars, to be expended by the governor to defray the contingent expenses of the Territory; and there shall also be appropriated annually, a sufficient sum, to be expended by the secretary of the Territory, and upon an estimate to be made by the secretary of the treasury of the United States, to defray the expenses of the legislative assembly, the printing of the laws, and other incidental expenses; and the secretary of the Territory shall annually account to the secretary of the treasury of the United States for the manner in which the aforesaid sum shall have been expended.

Sec. 12. And be it further enacted, That the inhabitants of the said territory shall be entitled to all the rights, privileges, and immunities heretofore granted and secured to the Territory of Wisconsin, and to its inhabitants; and the existing laws of the Territory of Wisconsin shall be extended over said Territory, so far as the same be not incompatible with the provisions of this act, subject, nevertheless, to be altered, modified or repealed by the governor and legislative assembly 
of the said Territory of Iowa; and, further, the laws of the United States are hereby extended over, and shall be in force in said Territory, so far as the same, or any provision thereof, may be applicable.

Sec. 13. And be it further enacted, That the legislative assembly of the Territory of Iowa shall hold its first session at such time and place, in said Territory, as the governor thereof shall appoint and direet; and at said session, or as soon thereafter as may by them be deemed expedient, the said governor and legislative assembly shall proceed to locate and establish the seat of government for said Territory, at such place as they may deem eligible, which place, however, shall thereafter be subject to be changed by the governor and legislative assembly. And the sum of twenty thousand dollars, out of any money in the treasury, not otherwise appropriated. is hereby granted to the said Territory of Iowa, which shall be applied, by the governor and legislative assembly thereof, to defray the expenses of erecting public buildings at the seat of government.

Sec. 14. And be it further enacted, That a delegate to the House of Representatives of the United States, to serve for the term of two years, may be elected by the voters qualified to elect members of the legislative assembly who shall be entitled to the same rights and privileges as have been granted to the delegates from the several territories of the United States to the said House of Representatives. The first election shall be held at such time and place or places, and be conducted in such manner as the governor shall appoint and direct. The person having the greatest number of votes shall be declared by the governor to be duly elected, and a certificate thereof shall be given to the person so elected.

Sec. 15. And be it further enacted, That all suits, process, and proceedings, and all indictments and informations, which shall be undetermined on the third day of July next, in the distriet courts of Wisconsin Territory, west of the Mississippi river, shall be transferred to be heard, tried, prosecuted and determined in the district courts hereby established, which may include the said counties.

Sec. 16. And be it further enacted, That all justices of the 
peace, constables, sheriffs, and all other executive and judicial officers, who shall be in the office on the third day of July next, in that portion of the present Territory of Wisconsin, which will then, by this act, become the Territory of Iowa, shall be, and are hereby authorized and required to continue to exercise and perform the duties of their respective offices, as officers of the Territory of Iowa, temporarily, and until they or others shall be duly appointed to fill their places by the territorial government of Iowa, in the manner herein directed: Provided, That no officer shall hold or continue in office by virtue of this provision, over twelve months from the said third day of July next.

Sec. 17. And be it further enacted, That all eauses which shall have been or may be removed from the courts held by the present Territory of Wiseonsin, in the counties west of the Mississippi river, by appeal or otherwise, into the supreme court for the Territory of Wisconsin, and which shall be undetermined therein on the third day of July next, shall be certified by the elerk of the said supreme court, and transferred to the supreme court of said Territory of Iowa, there to be proceeded in to final determination, in the same manner that they might have been in the said supreme court of the Territory of Wisconsin.

Sec. 18. And be it further enacted, That the sum of five thousand dollars be, and the same is hereby, appropriated, out of any money in the Treasury not otherwise appropriated, to be expended by, and under the direction of, the Governor of said Territory of Iowa, in the purchase of a library, to be kept at the seat of government, for the accommodation of the governor, legislative assembly, judges, secretary, marshal, and attorney of said Territory, and such other persons, as the governor and legislative assembly shall direct.

Sec. 19. And be it further enacted, That from and after the day named in this act for the organization of the Territory of Iowa, the term of the members of the Council and House of Representatives of the Territory of Wisconsin shall be deemed to have expired, and an entirely new organization of the Council and House of Representatives of the Territory of Wisconsin, as constituted by this act, shall take place as 
follows: As soon as practicable, after the passage of this act, the governor of the Territory of Wisconsin shall apportion the thirteen members of the Council, and twenty-six members of the House of Representatives among the several counties or districts comprised within said Territory, according to their population, as nearly as may be, (Indians excepted.) The first election shall be held at such time as the governor shall appoint and direct, and shall be conducted, and returns thereof made in all respects according to the provisions of the laws of said Territory, and the governor shall declare the person having the greatest number of votes to be elected, and shall order a new election when there is a tie between two or more persons voted for, to supply the vacaney made by such tie. The persons thus elected shall meet at Madison, the seat of government, on such day as he shall appoint, but thereafter, the apportioning of the representation in the several counties, to the Couneil and House of Representatives, according to population, the day of their election, and the day for the commencement of the session of the legislative assembly shall be preseribed by law.

Sec. 20. And be it further enacted, That temporarily, and until otherwise provided by law of the legislative assembly, the governor of the Territory of Iowa may define the judicial distriets of said Territory, and assign the judges who may be appointed for said Territory, to the several districts, and also appoint the time for holding courts in the several counties in each district, by proclamation to be issued by him; but the legislative assembly, at their first or any subsequent session, may organize, alter, or modify such judicial districts, and assign the judges, and alter the times of holding the courts, or any of them.

APPRoved June 12, 1838.

The first Government sale of lands lying in this county (Des Moines) took place in November 1838; the principal part of the lands however were not offered at public sale until 1839 and 1840. Iowa Territorial Gazette and Advertiser, September 3, 1842. 
Copyright of Annals of Iowa is the property of State of Iowa, by \& through the State Historical Society of Iowa and its content may not be copied or emailed to multiple sites or posted to a listserv without the copyright holder's express written permission. However, users may print, download, or email articles for individual use. 